\title{
'Transnational Judicial Dialogue on International Law in Central and Eastern Europe' (ed. by Anna Wyrozumska), Wydawnictwo Uniwersytetu Łódzkiego, Łódź 2017, 503 pp., ISBN 978-83-8088-707-7
}

From the international law perspective, the rulings of domestic courts are considered as acts of states that can potentially trigger international state responsibility, with numerous examples, for instance, found in the domain of international human rights law. The case-law of domestic courts is also perceived as a manifestation of state practice, co-shaping the development of customary international law norms. However, a parallel, and perhaps even more predominant, discussion on domestic courts dealing with public international law has been put into frames of the so-called 'transnational judicial dialogue' or 'trans-judicial dialogue'. The scholarly literature on this topic dates back to the 1990s and the doctrinal interest seems to be growing ever since.

The book edited by Professor Anna Wyrozumska contributes to this trend by providing valuable outlook on how and when the domestic courts in Central and Eastern Europe (CEE) entered into dialogue on matters of international law. Before casting a closer look on the contents of the book,

* Associate Professor, Human Rights Department, Faculty of Law, Nicolaus Copernicus University (Toruń, Poland), e-mail: michal.balcerzak@umk.pl, ORCID: 0000-0002-6421-1742. 
it is worth to note that the latter in fact offers more than it promises in the title, since the authors do not focus exclusively on the 'dialogue' of domestic courts with international courts and tribunals. This is the dialogue that takes place when a domestic court engages by (at least) referring and (optimally) taking a stance to a pronouncement of an international court or other body having judicial or quasi-judicial competences under international law. According to the authors themselves, 'the key concept of the book, the judicial dialogue, is understood broadly as a practice of using any kind of cross-references to reasoning and interpretation of law conducted by other judges' (p. 11). A. Wyrozumska explains further that the notion of 'judicial dialogue' is 'elusive and gives rise to conceptual confusion' (p. 15). However, the authors undertook their review and research, not only on judicial dialogue in the above sense, but also even largely: on the place of international law in the domestic legal systems of the CEE states, and they provide illustration of domestic courts applying international law, not necessarily entering into dialogue with international courts and tribunals. The scope of the book is thus impressive, though it needs to be mentioned that 'transnational judicial dialogue' referred to in the title is just a part of a much broader picture presented inside. Thus, the title only partly covers its contents.

The reviewed book was meant to analyse the impact of Polish, Czech, Lithuanian, Hungarian, Russian and Ukrainian courts on international law and on strengthening of the rule of law through international law (p. 11). This could be regarded as a huge task and it is understandable that the results of the enquiry substantially differ on the country-by-country basis. But irrespective of the country-specific research and conclusions, the volume offers also an analysis of selected issues concerning judicial dialogue, such as the perspective of CEE constitutional courts engaged in the dialogue (I. Skomerska-Muchowska), dialogue between selected CEE courts and the European Court of Human Rights (M. Górski) or the practice of preliminary reference procedure under Article 267 of the Treaty on the Functioning of the European Union (TFEU) brought to the Court of Justice of the European Union by CEE courts (A. Czaplińska). Other co-authors undertook research on judicial dialogue in selected areas of Polish domestic law (contributions by J. Krzemińska-Vamvaka, M. Matusiak-Frącczak, M. Kowalski), as well as Lithuanian (E. Kuzborska), Ukrainian (I. Kolisnyk, T. Tsymbrivskyy) and Hungarian (E. Csatlós) law. The latter contributions follow a scheme by firstly outlining the features of the legal system under consideration and, in particular, the place of international law, in order 
to proceed to patterns of judicial dialogue illustrated by examples from case-law.

Reviewing a book of eleven sections on a chapter-by-chapter basis might be a tiresome experience, both for the readers as well as for the reviewer. Therefore, I just wish to highlight and comment on some selected contributions, while appreciating the overall good academic quality of the texts under consideration. Particularly noteworthy are those that analyse the 'judicial dialogue' between domestic courts and the European Court of Human Rights, notwithstanding the significance of another vital area, i.e. the preliminary reference procedure under Article 267 of the Treaty on the Functioning of the European Union. With respect to the first of these areas, M. Górski's contribution (pp. 233-296) provided the reader with informative illustrations of such a dialogue initiated by some Central and Eastern European courts. These examples were preceded by general remarks on the idea of 'dialogue' which was construed by the author in quite broad terms as including 'any form of (unilateral) reference in the reasoning of domestic court to the case law of the European Court of Human Rights' (p. 233). Whether unilateral references of a domestic court to the jurisprudence of the ECtHR should indeed be qualified as a form of dialogue could be a matter of debate. I believe it is much more preferable to consider such references by recourse to the theory of (non-binding) precedents and the latter's 'gravitational force' (R. Dworkin), with all its nuances. Understandably, it is within any author's liberty to offer their own concepts and definitions, however, the idea of 'one-way-only' judicial dialogue with all its classifications explained by M. Górski (mandatory vs. non-mandatory references; unifying vs. engaged; concurring vs. dissenting, etc.) bears close resemblance to the theory and typologies of precedents known not only in the Anglo-Saxon legal world, but also elsewhere, ${ }^{1}$ including in international law.

Be it as it may, another classification of 'dialogue' suggested by M. Górski is worth mentioning, and notably the one applying 'the criterion of appropriateness understood as the accuracy of the referring court's reasoning seeking (or failing) to involve references to other courts' case law' (p. 235). Along these lines, the author distinguishes 'proper dialogue' (referring to a 'proper' case), a 'fake or decorative one' as well as a 'failed one' (when a court missed an opportunity to refer to the case law of other courts at all when one

1 Among many authorities, see D.N. MacCormick, R.S. Summers (eds.), Interpreting Precedents. A Comparative Study, Darmouth 1997, passim. 
should reasonably expect it to do so). Even though it is based on a subjective criterion (i.e. 'appropriateness'), this typology makes much sense and allows in itself to express scholarly opinions on the quality of domestic court caselaw referring (or not referring) to the judgments of the ECtHR. Examples from all the above categories were provided by the author in his text; the typology was also applied by M.M. Matusiak-Frącczak on the references to international law by Polish common courts (pp. 333-358). Overall, the contribution of $\mathrm{M}$. Górski can be regarded as a thought-provoking voice in the discussion on the modalities and concerns over the usage of the Strasbourg Court's case law by the courts in Central and Eastern Europe.

In her part of the text, A. Czaplinska discussed the preliminary reference procedure under Article 267 of the TFEU. The inclusion of this type of judicial dialogue into the book on transnational judicial dialogue is I think, fully justified. In a way, questions from domestic courts of EU member states, followed by CJEU's rulings and the latter's subsequent application could be perceived as forms of the most 'genuine' judicial dialogue, assuming reciprocity and interaction. In her chapter, $\mathrm{A}$. Czaplinska outlined the essence of the preliminary reference procedure, with particular focus on its 'dialogue-generating features' as well as on doctrinal approaches to its characteristics. In subsequent sub-chapters, the author overviewed examples of CJEU's rulings delivered under Article 267 of the TFEU with respect to four CEE states: the Czech Republic, Hungary, Lithuania and Poland. Over the period of twelve years that were covered by the study (2004-2016), the number of questions submitted by domestic courts of the four CEE states mentioned above reached ca. 200 in total. This bulk of cases could not be discussed in one single article (also given the diversity of legal issues involved), but the author managed to identify the most significant examples. A. Czaplińska concludes that the quality of references from CEE states did not differ, in general, from the EU average and 'quite often national courts show courage to present, beside the factual and legal circumstances of the cases pending before them, their own considerations and problems that are subject of preliminary references' (p. 328).

In a chapter entitled 'International Refugee Law and Judicial Dialogue from the Polish Perspective' (pp. 365-394), M. Kowalski offered a thorough overview of the normative framework of this branch of law, with particular focus on its specificity and application in Central and Eastern Europe. Prior to discussing judicial dialogue on refugee in the context of Polish jurisprudence, the author notes the doctrinal views on the forms of judicial interactions, distinguishing between face-to-face interactions, IT-based communication and cross-citations (p. 374). According to M. Kowalski, the 
area of refugee law can be regarded as illustrative in this regard, given the activities of the International Association of Refugee Law Judges and the Judges' Network of the European Asylum Support Office. With respect to the Polish context of judicial dialogue on refugee law, the author observes that 'references to decisions of international courts and of national courts of foreign jurisdictions are not all frequent' (p. 376). The author refers to the accessibility of the latter decisions, however, it might not be surprising that the horizontal dimension of this 'dialogue' (i.e. between national courts) is much less visible than the vertical one, i.e. referring by domestic courts (and also administrative bodies delivering decisions in asylum cases) to case-law of international courts. Specific examples given by M. Kowalski prove that the milestones of the Strasbourg Court's case-law were included in the reasoning of the Refugee Board's decisions as well as that of some judgments of the administrative courts. Similarly, several references to the judgments of the Court of Justice of the European Union were also provided. $\mathrm{M}$. Kowalski mentioned also a notable example of the 'genuine' dialogue between international and national courts on issues concerning refugee law, i.e. the standards applicable to asylum claims based on sexual orientation (p. 381). Further issues discussed in the chapter include definitions of 'social groups' for the purposes of adjudicating asylum cases, applying the 'Internal Protection (Flight) Alternative Principle' (the 'IPA Principle'), ${ }^{2}$ as well as granting subsidiary protection and the denial of access to adequate medical treatment. In essence, although the author sees much room for improvement ('The Polish contribution to judicial dialogue on refugee law is rather modest and definitely could be more elaborate', p. 393), it appears that the Polish Refugee Board, as well as administrative courts could be regarded as 'participants' to the European judicial dialogue on refugee law.

While it is hard to draw uniform conclusions on how the CEE courts engage in transnational judicial dialogue, bearing in mind the diversity of constitutional and legislative settings, the overall impression of the survey and research undertaken by the authors could be moderately optimistic. None of the judicial systems analysed in the book appeared to be 'closed' or extremely reluctant to the influence of international law, manifested in the practice of domestic courts. Obviously, as noted by the Editor of the volume (p. 88):

2 The 'IPA Principle' denotes a concept of distinguishing between safe and unsafe parts of a country (of an asylum-seeker's origin) for the purposes of determining asylum claims. See J. Schultz, The Internal Protection Alternative in Refugee Law, Brill-Nijhoff 2018. 
(...) the application of international law does not depend as much on the monistic or dualistic scheme, but on the broader, legal and also political context (...). The judges can be more (as in Poland and the Czech Republic) or less open to considerations of international law (as in Hungary, Lithuania, Russia or Ukraine).

Thus, the quality of judicial dialogue on matters of international law depends not only on legal or institutional setting, but also on the quality of education on public international law and EU law offered at universities, training centres and various forms of vocational training for judges and legal practitioners. Time will tell how the CEE courts would be developing their involvement in transnational dialogue on international law. One underused opportunity in this regard (which in fact is outside of the reach of the courts' themselves), could be indicated: Protocol no. 16 to the Convention for the protection of Human Rights and Fundamental Freedoms, ${ }^{3}$ which allows the highest courts and tribunals of state-parties to the Convention, to request the European Court of Human Rights to give advisory opinions on questions of principle relating to the interpretation or application of the rights and freedoms defined in the Conventions or its protocols. It is deeply disappointing that the interest of CEE states into the ratifying of this protocol is so weak. As of 2019, only Ukraine and Lithuania were bound by its provisions, while the Czech Republic, Hungary, Poland and the Russian Federation were not even signatories.

To conclude, the book edited by Prof. A. Wyrozumska constitutes a solid overview of the practice of domestic courts in Central and Eastern Europe with respect to engaging in dialogue with other courts on matters of international and EU law. It can reasonably be expected that the volume proves useful both for international, as well as constitutional lawyers. It should also be recommended to domestic court judges themselves, as well as to those responsible for curricula at training centres for judges and legal practitioners. Finally, it is praiseworthy that the full text of the book was made available in open-access mode at the website of the publisher (Łódź University Press). ${ }^{4}$

3 Adopted on 2.10.2013, entered into force on 1.8.2018. Council of Europe Treaty Series no. 214.

4 Full text available in open-access at the website of the publisher: Łódź University Press, www.wydawnictwo.uni.lodz.pl. 